〔Med. Entomol. Zool. Vol. 54 No. 1 p. 105-111 2003]

\title{
Studies on the pupal mosquitoes of Japan (8) A key to species of the genus Aedes (Diptera, Culicidae)
}

\author{
Kazuo TANAKA \\ Minamidai 2-1-39-208, Sagamihara, 228-0814 Japan \\ (Received: 7 November 2002; Accepted: 9 December 2002)
}

\begin{abstract}
A generic description and a key to 40 Japanese species of the pupa of the genus Aedes are given.
\end{abstract}

Key words: mosquito pupae, Aedes, key, Japan

As the conclusion of my series of studies on the pupa of the Japanese species of the genus Aedes (Tanaka, 1999, 2000a, 2000b, 2001, 2002a, 2002b, 2003), a generic description and a key to all Japanese species of the genus Aedes are presented here. Subgeneric characters have been found to be difficult to specify, and preparation of a key to subgenera was not attempted. Among 43 Japanese species, I could not examine pupae of nine species. Six of the nine, Ae. (Ochlerotatus) diantaeus, Ae.(Och.) vigilax, Ae. (Finlaya) albocinctus, Ae. (Stegomyia) aegypti, Ae. (Stg.) daitensis and Ae. (Edwardsaedes) bekkui, are incorporated into the key by utilizing published information. Of the remainder, Ae. (Och.) sp. (Ae. sticticus of Yamada, 1921), Ae. (Harbachius) nobukonis and Ae. (Verrallina) iriomotensis are excluded because of insufficient information.

The principles and methods of this work follow those of Tanaka, 1999 and 2001. I am indebted to Mr. Edward S. Saugstad for reviewing the manuscript.

\section{Genus Aedes Meigen}

Dorsal apotome divided; lateralia smooth or sometimes with traces of facets of compound eye. Trumpet more or less broadened towards or at apex, $2-5$ times as long as wide; pinna $1 / 10-3 / 5$ as long as trumpet. Setae 1-7-C almost constant in position; 8-C most often at level of trumpet base, sometimes slightly anteriad or posteriad of it; 11-C most often single, at most three branched, rather thick basally. Abdominal tergum I with or without microreticulation; terga II-VIII more often covered with short transverse ridges bearing one or a few caudally directed minute spicules, these ridges tending to become imbrication laterally, terga II-VIII rarely covered with microreticulation. Setae 0-I lacking; 0-II-VIII minute. Seta 1-I (float hair) usually with about 10 or more stout primary branches which are subdivided into numerous, sometimes 100 or more, fine secondary branches, rarely with primary branches only; 1-II often with many barbed branches. Setae 2 short, usually rather stout; 2-II usually laterad of 3-II; 2 III-V more often anteromesad of respective setae 1; 2-VI and -VII variable in position relative to respective setae 1 , usually closer to them than in preceding segments. Seta 3-I usually very close to 2-I, rarely removed laterally; 3 -II and -III often rather strong and longest of setae of respective segments; 3 -III usually close to 1 III; 3-IV-VII ordinary slender setae, usually longer than respective setae 4 in IV and $\mathrm{V}$, variable in VI and shorter than seta 4 in VII. Setae 4 slender, short in I-IV and gradually longer in more posterior seg- 
ments; 4-VII anterolaterad of 5-VII; 4-VIII more often single or two branched, at most 5 branched. Seta 5-I cephalad of 4-I; 5-II longer than and rarely mesad of 4-II; 5III longer than and usually mesad of 4-III; 5-IV-VI usually, often conspicuously, strong and longest of setae of respective segments; 5-VII usually weak, shorter than 4-VII. Setae 6-I and -II sometimes more or less strong and longest of setae of respective segments; 6-III-VI more often distinctly shorter than 6-I and -II, rarely as strong as them; 6-VII usually short, multibranched and posteromesad of 9-VII, rarely anteromesad of it. Setae 7-I and -II usually equal to or shorter than respective setae 6 , rarely longer than them; 7 -III-V short, often multibranched; $7-\mathrm{V}$ usually a little longer than 7-III and -IV and 8-V; 7 VI and -VII most often single and longer than 7-III-V. Seta 8-I always and 8-II usually lacking; 8-III-VII short and usually multibranched; 8-VII usually a little stronger than 8-III-VI. Setae 9-I and -II short and weak; 9-III-VI very short except in Stegomyia; 9-VII usually more or less differentiated, sometimes similar to 9-VIII in magnitude, rarely short and weak; 9-VIII usually at posterolateral corner of the segment, rarely removed anteriorly, mostly variously developed, often with many strongly barbed and/or subdivided branches, sometimes long and unequal branches. Setae 10-I and -II usually lacking; 10-III-VII rather long slender setae. Setae 11-I and -II usually lacking; 11-III-VI short, usually single; 11-VI and -VII laterad of respective setae 10; 11-VII longer than 11-III-VI. Seta 12 usually lacking. Seta 13-I a single or multicuspid short peg-like seta; 13-IIVII usually lacking. Setae 14-I and -II lacking; 14-III-VII short, close together at middle near anterior margin of respective sterna; 14-VIII removed posterolaterally, longer than 14-III-VII and usually about as long as 2-VII. Segment VIII only with setae $0,4,9$ and 14. Median caudal lobe (segment IX) simple, usually without setae. Paddle circular or elliptical, sometimes roughly oblong, more or less fringed with minute dentiform spicules in most groups, or filamentous spicules in Scutellaris group of subg. Stegomyia; index 0.891.98. Seta 1-Pd mostly single, sometimes branched; 2 -Pd rarely present.

Supernumerary setae. The following supernumerary setae have often or occasionally been found. 13-, 14- and 15-C; 8-II; 10 II and -VIII; 11-I, -II and -VIII; 12-I, -II, -III, -IV, -V, -VI and -VII; 13-II, -III, -V and -VI; 14-IX; 2- and 3-Pd.

\section{Key to Japanese Species of the Pupa of the Genus Aedes}

1. Paddle fringed with filamentous spicules. (scutellaris group) ................2

- Paddle fringed with dentiform spicules, or smooth on margins. $\quad . . . . . .8$

2. Setae 6-III-V as long as setae 9 of respective segments (after Miyagi and Toma, 1980). [Daitô-shotô] ................Ae. (Stegomyia) daitensis

- Setae 6-III-V longer than setae 9 of respective segments. ...................

3. Filamentous fringe spicules of paddle short, about as long as seta 2-VII or shorter; paddle elongate elliptical, index 1.74 (1.60-1.89); 9-VIII rather short, not reaching fringed area of paddle. [Hokkaidô; Honshû; Kyûshû; Korean Peninsula; Sakhalin; northeastern China; west Siberia] Ae. (Stg.) galloisi

- Filamentous fringe spicules of paddle long, about as long as setae 2-I and -II, distinctly longer than 2-VII; paddle elliptical or ovate, index ca 1.4 (1.131.71); 9-VIII reaching fringed area of paddle.

4. Seta 6-C rather strong, usually next to 7-C in length and longer than 4- and 5C; male genital lobe long, 0.80 (0.720.85) length of paddle. [Shikoku; Kyûshû; Ryukyu Arch.] Ae. (Stg.) riversi 
- Seta 6-C usually shortest of prothoracic setae 4-7-C; male genital lobe short, ca $0.6 \quad(0.52-0.73)$ length of paddle. . .5

5. Seta 9-III almost always shorter than 2-III; 9-VI almost always less than twice as long as 2-VI, never more than three times as long as it. .............6 6

- Seta 9-III almost always longer than 2-III; 9-VI more than twice as long as 2 -VI, often more than three times as long as it. ..7

6. Seta 2-III usually mesad of 1-III; 2-IV and $-\mathrm{V}$ always mesad of setae 1 of respective segments; $6-\mathrm{C}$ not much shorter than 4-, 5- and 7-C. [Honshû; Shikoku; Kyûshû; Ryukyu Arch.; Daitô-shotô; Ogasawara-guntô; Korean Peninsula; Cheju-do; China; Oriental Region; Marianas; Hawaiian Is.; New Guinea; northern Australia; Chagos Arch.; Seychelle; Reunion; Mauritius; Madagascar; French Somalia; imported to the Americas, New Zealand, Fiji, Europe and Africa] Ae. (Stg.) albopictus

- Seta 2-III laterad of 1-III; 2-IV and -V usually laterad of or tandem with setae 1 of respective segments; $6-\mathrm{C}$ distinctly shorter than 4-, 5- and 7-C. [Hokkaidô; Honshû; Shikoku; Kyûshû; Korean Peninsula; Cheju-do; northeastern China; southern Prymorye] .........Ae. (Stg.) flavopictus flavopictus

7. Seta 9-V usually at least twice as long as 2-V; 9-VI not more than twice as long as 9-V; 2-VII very rarely laterad of 1-VII. [Amami-guntô; Okinawaguntô] ...Ae. (Stg.) flavopictus downsi

- Seta 9-V almost always less than twice as long as 2-V; 9-VI often (59\%) twice or more than twice as long as 9$\mathrm{V}$; 2-VII very rarely mesad of 1-VII. [Yaeyama-guntô] Ae. (Stg.) flavopictus miyarai

8. Posterior margin of sternum II with various-sized dentiform spicules. Seta 1-Pd single, short, 0.06 0.14 ( $\overline{\mathrm{x}} 0.10)$ length of paddle. [Hokkaidô; Honshû; Shikoku; Kyûshû; Ryukyu Arch.; Daitô-shotô; Korean Peninsula; Cheju-do; Sakhalin; Prymorye; East Baikal; Mongolia; China]

.....Ae. (Aedimorphus) vexans nipponii

- Posterior margin of sternum II simple.

9. Setae 1-, 5- and 10-VII remarkably thick. [Honshû; Shikoku; Kyûshû; Korean Peninsula; Cheju-do; Taiwan; southern China]

Ae. (Finlaya) hatorii

- Setae 1-, 5- and 10-VII ordinary slender setae. ...............................10

10. Seta 3-I about at middle between 2-I and 4-I; 5-IV and -V shorter than or about as long as 1-IV and -V respectively. [Miyako-guntô; Yaeyamaguntô; Korean Peninsula; Cheju-do; Oriental Region; Timor; Amboina; northern Australia]

...Ae. (Neomelaniconion) lineatopennis

- Seta 3-I closer to 2-I than to 4-I, usually very close to 2 -I; 5 -IV and -V distinctly longer and stouter than 1-IV and $-\mathrm{V}$ respectively $. . . \ldots \ldots \ldots \ldots \ldots . . . .11$

11. Seta 1-Pd very short, 0.05-0.07 ( $\overline{\mathrm{x}}$ 0.06 ) length of paddle, $2-4$ (most often three) branched; 9-VIII a little cephalad of posterolateral corner of the segment. [Honshû; Kyûshû; Oriental Region; Papuan Subregion; northern Australia] ...Ae. (Adm.) alboscutellatus

- Seta 1-Pd at least $1 / 8$ as long as paddle, if short, then it is single; 9 -VIII at posterolateral corner of the segment. . .12

12. Seta 6-C longest of 4-7-C and rather strong; 2-III-V never mesad of respective setae 1 , and at middle to posterior $1 / 3$ of respective segments. (aegypti group) ...............................13

- Seta 6-C shortest of 4-7-C; 2-III-V usu- 
ally mesad of respective setae 1 , and more or less close to posterior margin of the segment. .14

13. Trumpet long, cylindrical and broadened at apex; seta 2-III almost always anterolaterad of 3-III; 2-IV-VI usually placed more anterolaterally and often anterolaterad of respective setae 3 . [Ogasawara-guntô] ...Ae. (Stg.) wadai

- Trumpet short, broadened from base to apex; seta 2-III anteromesad of 3-III; 2-IV-VI usually placed more posteromesally and often mesad of respective setae 3 (after Belkin, 1962, Fig. 313). [Cosmotropical] ......Ae. (Stg.) aegypti

14. Seta 1-I composed of only primary branches. Seta 5-C longest of cephalothoracic setae and as long as or longer than trumpet; 10-C almost always single. ................................15

- Seta 1-I composed of about 10-20 thick primary branches and numerous (sometimes more than 100) fine secondary branches. ...............16

15. Trumpet wider, index 3.64; seta 5-VI subequal to $5-\mathrm{V}$ in length, $1.29-1.76(\overline{\mathrm{x}}$ 1.58) length of tergum VII. [Hokkaidô; Honshû; Kyûshû; Korean Peninsula; Sichuan; Yunnan; northern India] ....................Ae. (Fin.) oreophilus

- Trumpet narrower, index 4.23-5.30; seta 5-VI usually shorter than $5-\mathrm{V}$, 0.97-1.54 ( $\overline{\mathrm{x}} 1.23$ ) length of tergum VII. [Kyûshû; Ryukyu Arch.] Ae. (Fin.) watasei

16. Seta 6-VII anteromesad of 9-VII. Seta 3-C longest of cephalothoracic setae and distinctly longer than 5- and 7-C. (aureostriatus group) ...............17

- Seta 6-VII posteromesad of 9-VII. .19

17. Seta 7-I 1-3 (most often single) branched; 9-VIII 3-9 (most often eight) branched. [Hokkaidô; Honshû; Kyûshû; Korean Peninsula]
Ae. (Fin.) kobayashii

- Seta 7-I 2-5 (most often three or four) branched; 9-VIII 9-19 (most often 10 or 11) branched. 18

18. Subspecies from Amami- and Okinawa-guntô.

......Ae. (Fin.) okinawanus okinawanus

- Subspecies from Yaeyama-guntô and Taiwan.

Ae. (Fin.) okinawanus taiwanus

19. Seta 5-II mesad of 4-II. .............20

- Seta 5-II laterad of 4-II. ..............22

20. Trumpet narrow, index $3.06-4.18(\overline{\mathrm{x}}$ 3.52); seta 7-I as long as 6-I; 3-II short, distinctly shorter than 5-II; 9-VIII long, 0.54 length of paddle, with only several branches, median branches distinctly longer than lateral branches; paddle elliptical, index 1.43-1.45

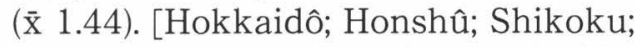
Yakushima] ......Ae. (Fin.) koreicoides

- Trumpet wide, index 2.06-3.13; seta 7I longer than 6-I; 3-II long, distinctly longer than 5-II; 9-VIII short, 0.230.42 length of paddle, with 6-19 (usually about 10) subequal branches; paddle broadly rounded, index 0.891.07. (togoi group) .....................21

21. Seta 2-Pd absent; 1-II, 8-VII and 9-VII 10-36 (most often 13-15), 3-11 (most often five) and 4-9 (most often six) branched respectively. [Chishima; Hokkaidô; Honshû; Shikoku; Kyûshû; Ryukyu Arch.; Daitô-shotô; Ogasawara-guntô; Marcus Is.; Korean Peninsula; Cheju-do; southern Prymorye; Sachalin; continental China; Taiwan; Hainan; Thailand; Malaya; North America] ................Ae. (Fin.) togoi

- Seta 2-Pd present; 1-II, 8-VII and 9-VII 2-8 (most often five), 1-4 (most often two) and 2-5 (most often three) branched respectively. [Ogasawaraguntô] ..................e. (Fin.) savoryi

22. Setae 3-, 5- and 7-C strongly devel- 
oped and much longer than trumpet (7-C longest); 6-III-VI strong and as well developed as 6-I and -II, often with unequal branches. (seoulensis group) ..............................23

- Seta 3-, 5- and 7-C slender and shorter than trumpet; 6-III-VI weak and much shorter than 6-I and -II. .24

23. Setae 3-, 4-, 5- and 7-C 2-5, 2-4, 1-2 and $2-4$ branched respectively. [Chikuzen-Okinoshima; Korean Peninsula; north China] ......Ae. (Fin.) seoulensis

- Setae 3-, 4-, 5- and 7-C 7-10, 5-8, 3-5 and $6-8$ branched respectively (after Chow and Mattingly, 1951). [Iriomotejima; Taiwan; Sichuan; Yunnan; western Himalayas; southern India]

Ae. (Fin.) albocinctus

24. Seta 1-C longest of cephalothoracic setae, and about as long as trumpet. Seta 9-VIII long, 0.49-0.76 (usually $2 / 3$ ) length of paddle, with 2-4 median branches distinctly longer than lateral branches; paddle elliptical, index 1.34-1.90, inner lobe as wide as outer lobe. (nipponicus group) ...25

- All cephalothoracic setae including 1C short, weak and distinctly shorter than trumpet. .26

25. Species from Palaearctic East Asia (Hokkaidô; Honshû; Shikoku; Kyûshû; Korean Peninsula; southern Prymorye; continental China). Ae. (Fin.) nipponicus

- Species from Amami- and Tokaraguntô, Ryukyu Archipelago. .Ae. (Fin.) nishikawai

26. Seta 8-C caudad of level of trumpet base. (japonicus group) 27

- Seta 8-C at or cephalad of level of trumpet base. .........................29

27. Seta 4-VIII almost always two or three branched, very rarely single; 6 -C usually 2-4 branched, rarely single; 8 -VII often (71\%) 4-7 branched. Outer lobe of paddle entirely spiculate. [Yaeyama-guntô]

........Ae. (Fin.) japonicus yaeyamensis

- Seta 4-VIII more often (77-93\%) single; 6 -C almost always single, very rarely branched; 8-VII almost always 1-3 branched. .28

28. Paddle usually somewhat angulate at apex and/or at middle of outer margin, with outer lobe usually entirely spiculate; seta 6-VII usually shorter and weaker than 9-VII. [Amami-guntô]

........Ae. (Fin.) japonicus amamiensis

- Paddle usually evenly and strongly rounded through outer margin to apical half of inner margin, with outer lobe at most indistinctly spiculate except for marginal area; seta 6-VII often as long and strong as 9-VII. [Hokkaidô; Honshû; Shikoku; Kyûshû; southern Korea; Cheju-do] Ae. (Fin.) japonicus japonicus

29. Seta 6-VII tandem with (and caudad of) 9-VII (after Mogi, 1977). [Hokkaidô; Honshû; Kyûshû] Ae. (Edwardsaedes) bekkui

- Seta 6-VII posteromesad of 9-VII.

30. Abdominal terga I-VIII with very distinct microreticulation. [Ryukyu Arch.; Philippines] Ae. (Geoskusea) baisasi

- Abdominal terga II-VIII usually without distinct microreticulation, but covered with distinct or indistinct short transverse ridges bearing one or a few posteriorly directed minute spicules. ..31

31. Seta 1-II about as long as 2-II, or only a little longer than it, almost always single or two branched, very rarely three or four branched. Seta 3-I constantly single. [Hokkaidô; Holarctic Region] ...Ae. (Ochlerotatus) intrudens

- Seta 1-II usually distinctly longer 
than 2-II, and with four or more (up to about 20) branches; in communis, 1-II about as long as 2-II but with four or more (up to 12) branches, and 3-I 2-4 branched. .32

32. Seta 9-VII not differentiated, as long as or shorter than 6-VII. ...............33

- Seta 9-VII more or less differentiated, longer and stouter than 6-VII. ......34

33. Seta 2-I single. Median caudal lobe wider, 0.6 as wide as segment VIII; setae 4-VIII more widely separated from each other, distance between them 0.7 as wide as segment VIII. [Yaeyama-guntô]

Ae. (Neomacleaya) atriisimilis

- Seta 2-I with two or more branches (after Darsie, 1957). [Hokkaidô; Holarctic Region] .........Ae. (Och.) diantaeus

34. Setae 5-IV-VI almost always with two or more (up to 4 ) branches. ........35

- Setae 5-IV-VI almost always single, very rarely two branched, exceptionally three branched. .39

35. Seta 3-I single; 9-VIII usually single, rarely two branched. [Hokkaidô; Honshû; Prymorye; Sakhalin]

......................Ae. (Aedes) yamadai

- Seta 3-I 2-4 branched, very rarely single (in excrucians); if single, then 9VIII four or more branched. .........36

36. Seta 1-III almost always (92\%) with eight or more (up to 15) branches, very rarely with six or seven; paddle broader, index 1.18 (1.08-1.36); 2-VII very often (79\%) mesad of $1-\mathrm{VII}$, rarely (14\%) laterad of it. [Hokkaidô; Honshû; Shikoku; Kyûshû; Holarctic Region; Mexico] ...Ae.(Och.) dorsalis

- Seta 1-III almost always with seven or fewer branches, very rarely with eight or nine (in communis); paddle narrower, index ca. 1.4 (1.14-1.67); 2-VII variable. .37
37. Seta 6-I long, $1.61(1.05-1.92)$ length of tergum I, always much longer than 7 I. [Hokkaidô; Holarctic Region] Ae. (Och.) excrucians

- Seta 6-I short, 0.83 (0.50-1.21) length of tergum I, as long as or shorter than 7-I. ..38

38. Seta 1-IV-VI about half as long as respective next terga; paddle usually narrower, index 1.14-1.61 ( $\overline{\mathrm{x}} 1.37$ ). [Hokkaidô; Holarctic Region] Ae. (Och.) communis

- Setae 1-IV-VI much less than half as long as respective next terga; paddle usually wider (after Belkin, 1962, Fig. 268). [Kuroshima, Ryukyu Arch.; Oriental and Australian Regions]

Ae. (Och.) vigilax

39. Seta 6-I always longer than 7-I, 0.812.00 length of tergum I; 1-IV shorter, usually less than half as long as next tergum.

- Seta 6-I at most as long as 7-I, rarely slightly longer than it (in akkeshiensis), ca. $0.67 \quad(0.23-1.15)$ length of tergum I; 1-IV longer, usually more than half as long as next tergum, sometimes longer than it. ...........41

40. Seta 3-I single; 9-VIII mostly single, rarely two or three branched.

.........Ae. (Aed.) esoensis [Hokkaidô; Honshû; Korean Peninsula; northeastern China; Sakhalin; eastern Siberia], and Ae. (Aed.) sasai [Hokkaidô; Honshû; Korean Peninsula; Prymorye; northeastern China]

- Seta 3-I almost always two branched, very rarely single or three branched; 9 -VIII 2-8 (most often three) branched. [Hokkaidô; Holarctic Region] Ae. (Och.) punctor

41. Seta 1-II with five or more (up to 15) branches; 6-I short, 0.39 (0.23-0.67) length of tergum I, often (69\%) shorter than 7-I, never longer than it. [Hokkaidô] 
Ae. (Och.) impiger daisetsuzanus

- Seta 1-II almost always with four or fewer branches, very rarely with five; 6-I ca. $0.77 \quad(0.43-1.15)$ length of tergum I, as long as or longer than 7-I. ........................................42

42. Seta 5-III usually single, rarely two branched, usually more than half as long as tergum III. [Hokkaidô]

Ae. (Och.) hokkaidensis

- Seta 5-III usually 2-5 branched and less than half as long as tergum III.

43. Seta 9-VII almost always (98\%) single, very rarely two branched. [Chishima; Hokkaidô] ......Ae. (Och.) akkeshiensis

- Seta 9-VII very often (75\%) two branched, otherwise single. [Honshû] .Ae. (Och.) hakusanensis

\section{REFERENCES}

Belkin, J. N. 1962. The mosquitoes of the South Pacific (Diptera, Culicidae). 2 vols., 608 and 412 pp. University of California Press, Berkeley and Los Angeles.

Chow, C. Y. and Mattingly, P.F. 1951. The male genitalia and early stages of Aedes (Finlaya) albocinctus Barraud and Aedes (Finlaya) albotaeniatus mikiranus Edwards with some notes on related species. Proc. R. Entomol. Soc. Lond. (B), 20: 80-90.

Darsie, Jr., R. F. 1957. Notes on American mosquito pupae II. The Aedes (Ochlerotatus) punctor sub- group, with key to known Nearctic Aedes pupae (Diptera, Culicidae). Ann. Entomol. Soc. Am., 50: 611-620.

Miyagi, I. and Toma, T. 1980. A new species of Aedes (Stegomyia) from Daito Islands, Ryukyu, Japan (Diptera: Culicidae). Mosq. Syst., 12: 428-434.

Mogi, M. 1977. A new species of Aedes (Diptera: Culicidae) from Japan. Trop. Med. (Nagasaki), 19: 129-140.

Tanaka, K. 1999. Studies on the pupal mosquitoes (Diptera, Culicidae) of Japan. (1) Aedes (Ochlerotatus). Jpn. J. Syst. Entomol., 5: 105-124.

Tanaka, K. 2000a. Studies on the pupal mosquitoes (Diptera, Culicidae) of Japan. (2) Aedes (Aedes). Jpn. J. Syst. Entomol., 6: 1-9.

Tanaka, K. 2000b. Studies on the pupal mosquitoes (Diptera, Culicidae) of Japan. (3) Aedes (Stegomyia). Jpn. J. Syst. Entomol., 6: 225-247.

Tanaka, K. 2001. Studies on the pupal mosquitoes of Japan (4). Supernumerary setae found in species of Aedes (Stegomyia) (Diptera, Culicidae). Jpn. J. Syst. Entomol., 7: 47-57.

Tanaka, K. 2002a. Studies on the pupal mosquitoes of Japan (5). Four subspecies of Aedes (Finlaya) japonicus Theobald, including subsp. shintienensis from Taiwan (Diptera, Culicidae). Jpn. J. Syst. Entomol., 8: 63-77.

Tanaka, K. 2002b. Studies on the pupal mosquitoes of Japan (6). Aedes (Finlaya) (Diptera, Culicidae). Jpn. J. Syst. Entomol., 8: 137-177.

Tanaka, K. 2003. Studies on the pupal mosquitoes of Japan (7). Subgenera Aedimorphus, Geoskusea, Neomelaniconion and Neomacleaya of the genus Aedes (Diptera, Culicidae). Jpn. J. Syst. Entomol., 9: in press. 